\title{
PENGARUH VARIASI UMUR BETON TERHADAP CEPAT RAMBAT GELOMBANG DENGAN MENGGUNAKAN METODE NON DESTRUCTIVE TEST
}

\author{
Alif Iqbal Nur Hidayat ${ }^{1}$, Indra waluyohadi ${ }^{2}$, Sugeng P. Budio ${ }^{2}$ \\ ${ }^{1}$ Mahasiswa, Program Sarjana, Jurusan Teknik Sipil, Fakultas Teknik \\ Universitas Brawijaya \\ ${ }^{2}$ Dosen, Jurusan Teknik Sipil, Fakultas Teknik \\ Universitas Brawijaya \\ Jalan MT. Haryono 167, Malang 65145, Jawa Timur, Indonesia \\ email : alif.iqbalhidayat@gmail.com
}

\begin{abstract}
Field testing is divided into 2 tests i.e. by destroying test structures or destructive tests and without destroying the structure or called a non-destructive test (NDT) One of them using the ultrasonic pulse rate (UPV). The study used the PUNDIT PL-200 tool to perform a concrete density analysis process based on the parameters generated from the UPV tool. The parameters taken on this test are rapid ultrasonic wave velocity. The study used a cylinder test object with a diameter of $15 \mathrm{~cm}$ and a height of $30 \mathrm{~cm}$. Test objects are differentiated into 4 age of concrete 7 days, 14 days, 21 days, and 28 days. The results that get in the study's quick value of wave vines are constantly increasing according to the age
\end{abstract}

Keywords: Pulse velocity, Age of concrete, concrete, Ultrasonic Pulse Velocity, Compressive.

\section{PENDAHULUAN}

Beton merupakan material yang sering digunakan di bidang konstruksi. Beton diperoleh dari hasil pencampuran antara semen, air, agregat halus, agregat kasar, dengan perbandingan tertentu dan dapat ditambah dengan bahan tambahan campuran (admixture). Pada era sekarang ini beton merupakan bahan penyusun utama dari suatu konstruksi karena memiliki kemampuan untuk mendistribusikan beban serta kuat dalam menahan gaya tekan.

Namun inovasi terkait beton tidak berhenti disitu saja. Banyak sekali modifikasi yang dilakukan pada beton guna meningkatkan kekuatan serta kegunaannya. Seperti yang disebutkan di atas bahwa beton hanya kuat untuk menahan gaya tekan. Nilai kuat tariknya hanya berkisar 9\% - $15 \%$ saja dari kuat tekannya. Oleh sebab itu, beton termasuk material yang bersifat getas yang berarti ketidakmampuan material untuk berdeformasi plastis. Solusi dari permasalahan tersebut adalah ditambahkan tulangan baja guna menahan gaya tarik.

Pengujian pada beton dilakukan dengan 3 cara yaitu dengan pengujian sebelum pengecoran, yang dilakukan dengan cara Slump test yang harus memenuhi nilai Slump yang ditentukan. Lalu ada pengujian di laboratorium yaitu dengan cara mengambil beberapa sampel beton segar sebelum pengecoran untuk diuji di laboratorium. Beton tersebut disimpan hingga umur beton 28 hari kemudian dilakukan pengujian. Pengujian ini menghasilkan hasil yang akurat, sebab data kekuatan beton diperoleh dari uji sampel secara langsung. Namun dalam pengujian ini memiliki kekurangan yaitu hasil pengujian kurang mewakili kualitas beton aktual pada struktur yang telah jadi. Pada struktur yang telah jadi, kualitas beton mengalami perbedaan. Perbedaan ini disebabkan karena proses pengerjaan beton serta kondisi lingkungan di lapangan misalnya kelembaban, temperatur, dan faktor lainnya. Faktor-faktor tersebut tidak dapat diketahui hanya melalui uji laboratorium saja. Maka dari itu dilakukan percobaan dengan sampel kering di lapangan.

Pengujian di lapangan dibagi menjadi 2 yaitu pengujian secara merusak struktur bangunan (destructive test) dengan cara pengambilan sampel inti dari beton structural. Lalu dengan cara tanpa merusak struktur atau yang disebut Non Destructive Test (NDT) salah 
satunya dengan menggunakan Ultrasonic Pulse Velocity $(U P V)$. Salah satu alat yang digunakan dalam pengujian $U P V$ disebut PUNDIT (Portable Ultrasonic Nondestructive Digital Indicating Tester). Alat tersebut mampu mengetahui cepat rambat gelombang ultrasonik. Dari data cepat rambat tersebut dapat ditunjukkan bagaimana kerapatan, homogenitas, serta ada tidaknya rongga di dalam beton. Pada penelitian sebelumnya [1][2] digunakan material yang berbeda beda sehingga diketahui bahwa perbedaan material penyusun menghasilkan cepat rambat yang berbeda.

\section{TINJAUAN PUSTAKA}

2.1. Ultrasonic Pulse Velocity (UPV)

Prinsip kerja dari metode ini adalah gelombang ultrasonik disalurkan dari transmitter transducer yang ditempatkan pada permukaan beton, setelah itu gelombang ultrasonik ini merambat melalui material beton menuju receiver transducer. Hasil pembacaan dari metode ini adalah kecepatan waktu tempuh gelombang ultrasonik yang akan diukur oleh alat PUNDIT (Portable Unit Non Destructive Indicator Tester) menggunakan satuan micro second.

Kecepatan gelombang ultrasonik dipengaruhi oleh kekakuan elastis dan kekuatan beton; pada beton dengan pemadatan yang kurang baik, atau mengalami kerusakan butiran material, gelombang UPV akan mengalami penurunan kecepatan. Perubahan kekuatan beton pada tes UPV ditunjukkan dengan perbedaan kecepatan gelombangnya; jika kecepatan turun, adalah tanda bahwa beton mengalami penurunan kekuatan, dan sebaliknya, jika kecepatan naik, adalah tanda bahwa kekuatan beton meningkat [3].

\subsection{Metode pengujian $U P V$}

Pada metode langsung, kedua transducer diletakkan saling berhadapan secara tegak lurus di dua permukaan beton yang berbeda. Panjang lintasan gelombang diukur berdasarkan jarak antara transmitter dan receiver. Karena posisi transducer yang diletakkan secara paralel, metode langsung menghasilkan transmisi energi gelombang yang paling besar dibandingkan metode lainnya [4][5].

\subsection{Perambatan Gelombang}

Ketika rambatan gelombang menemui bagian yang memiliki sifat material yang berbeda, sebagian energi dari gelombang tersebut akan tersebar dari lintasan awal gelombang. Misalnya dengan adanya rongga, retak, maupun partikel agregat dalam beton akan menyebarkan sebagian energi gelombang kompresi dari lintasan awal gelombang tersebut.

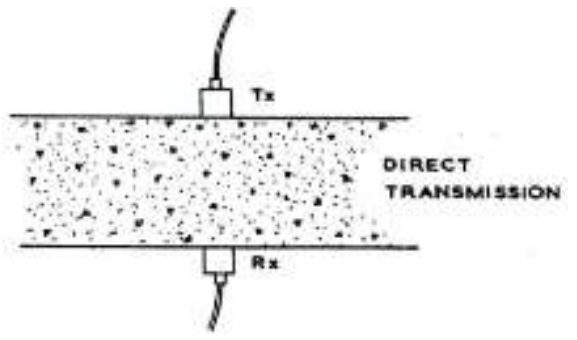

Gambar 1. Direct method (Metode langsung)

Tingkat penyebaran akan meningkat ketika panjang gelombang yang merambat besarnya lebih kecil atau sama dengan ukuran bagian penyebarnya, yang menimbulkan terjadinya gelombang tersebut mengalami redaman lebih cepat. Pada beton, batas maksimal dari frekuensi yang digunakan adalah $500 \mathrm{kHz}$ sebagaimana terkait dengan panjang gelombang sekitar $10 \mathrm{~mm}$, yang berada dalam rentang ukuran agregat kasar.

$$
V=\sqrt{\frac{K E}{\rho}}
$$

$$
\begin{aligned}
& \text { Dengan: } \\
& \mathrm{V} \quad=\text { kecepatan rambat, } \\
& \mathrm{K} \quad=\frac{1-\mu}{(1+\mu)(1-2 \mu)} \\
& \mathrm{E} \quad=\text { modulus elastis dinamis } \\
& \rho \quad=\text { kerapatan } \\
& \mu \quad=\text { rasio Poisson dinamis }
\end{aligned}
$$

\subsection{Kuat Tekan Beton}

Beton mempunyai kemampuan untuk menerima gaya tekan persatuan luas, ini yang disebut dengan kekuatan tekan (f'c). Kekuatan tekan beton sangat tinggi namun beton memiliki kuat tarik yang lemah. Kuat tekan beton merupakan salah satu parameter untuk mengetahui kualitas beton.

$$
\begin{aligned}
& \text { dengan : } \\
& \mathrm{f}^{\prime} \mathrm{c}=\text { tegangan tekan beton }(\mathrm{Mpa}) \\
& \mathrm{P}=\text { besar beban tekan }(\mathrm{N})
\end{aligned}
$$$$
\mathrm{f}^{\prime} \mathrm{c}=\frac{\mathrm{P}}{\mathrm{A}}
$$ 
A $=$ luas penampang beton $\left(\mathrm{mm}^{2}\right)$

\subsection{Korelasi Antara Umur Beton dan Kuat Tekan Beton}

Kekuatan tekan beton akan bertambah dengan naiknya umur beton [6]. Kekuatan beton akan naik secara cepat sampai umur 28 hari, tetapi setelah itu kenaikannya relatif kecil. Kekuatan tekan beton pada kasus tertentu terus akan bertambah sampai beberapa tahun ke depan. Biasanya kekuatan tekan rencana beton dihitung pada umur 28 hari. Untuk struktur yang menghendaki kekuatan awal yang tinggi, maka campuran dikombinasikan dengan semen khusus atau ditambah dengan bahan tambah kimia dengan tetap menggunakan jenis semen tipe I (OPC-1).

Reaksi dari senyawa kimia $\mathrm{C}_{3} \mathrm{~S}$ dan $\mathrm{C}_{2} \mathrm{~S}$ (Kalsium Silikat) dengan air menghasilkan CSH (kalsium silikat hidrat), dan $\mathrm{Ca}(\mathrm{OH})_{2}($ kalsium hidroksida). Perbedaan reaksi antara kedua senyawa tersebut dalam hal kecepatan dan panas reaksinya, kecepatan dan panas reaksi $\mathrm{C}_{3} \mathrm{~S}$ lebih besar dari pada $\mathrm{C}_{2} \mathrm{~S}$. Panas reaksi $\mathrm{C}_{3} \mathrm{~S}$ yang ditimbulkan sekitar $500 \mathrm{~J} /$ gram Panas reaksi $\mathrm{C}_{2} \mathrm{~S}$ yang ditimbulkan sekitar 350 J/gram. Senyawa-senyawa CSH yang dihasilkan merupakan komponen utama dalam penyumbang kekuatan semen portland, dan biasa disebut dengan tobermorite gel. Senyawa $\mathrm{C}_{3} \mathrm{~S}$ merupakan komponen penentu kekuatan awal semen portland, pada umur $1-28$ hari, hal ini disebabkan reaksi hidrasinya yang berlangsung cepat dan kadarnya yang tinggi. Sedangkan $\mathrm{C}_{2} \mathrm{~S}$ merupakan komponen penentu kekuatan akhir semen portland, peranannya baru terlihat 28 hari setelah pengikatan [7]. Rasio kuat tekan beton berdasarkan umurnya dapat di lihat pada Tabel 1.

Tabel 1. Rasio Kuat Tekan Beton Pada Berbagai Umur

\begin{tabular}{|c|c|c|c|c|c|c|c|}
\hline Unur beton (harl) & 3 & 7 & 14 & 21 & 28 & 90 & 355 \\
\hline $\begin{array}{c}\text { semes portand } \\
\text { bass }\end{array}$ & $Q 00$ & 2,155 & 0,88 & 0,95 & 100 & 120 & 135 \\
\hline $\begin{array}{l}\text { cemen portand } \\
\text { dergan lecuaten } \\
\text { aud tnge }\end{array}$ & 0,55 & 2,75 & Q9,90 & 0,95 & 1000 & 1,15 & 120 \\
\hline
\end{tabular}

\section{METODE PENELITIAN}

3.1. Variabel Penelitian

Ketiga variabel yang digunakan pada penelitian ini adalah :

1. Variabel bebas:

- Kecepatan gelombang ultrasonik hasil $U P V$ Test pada umur beton 7 hari.

- Kecepatan gelombang ultrasonik hasil $U P V$ Test pada umur beton 14 hari.

- Kecepatan gelombang ultrasonik hasil $U P V$ Test pada umur beton 21 hari.

- Kecepatan gelombang ultrasonik hasil $U P V$ Test pada umur beton 28 hari.

2. Variabel terikat :

- Cepat rambat gelombang dan kuat tekan beton normal

3. Variabel kontrol :

- Nilai slump test

\subsection{Tahapan Penelitian}

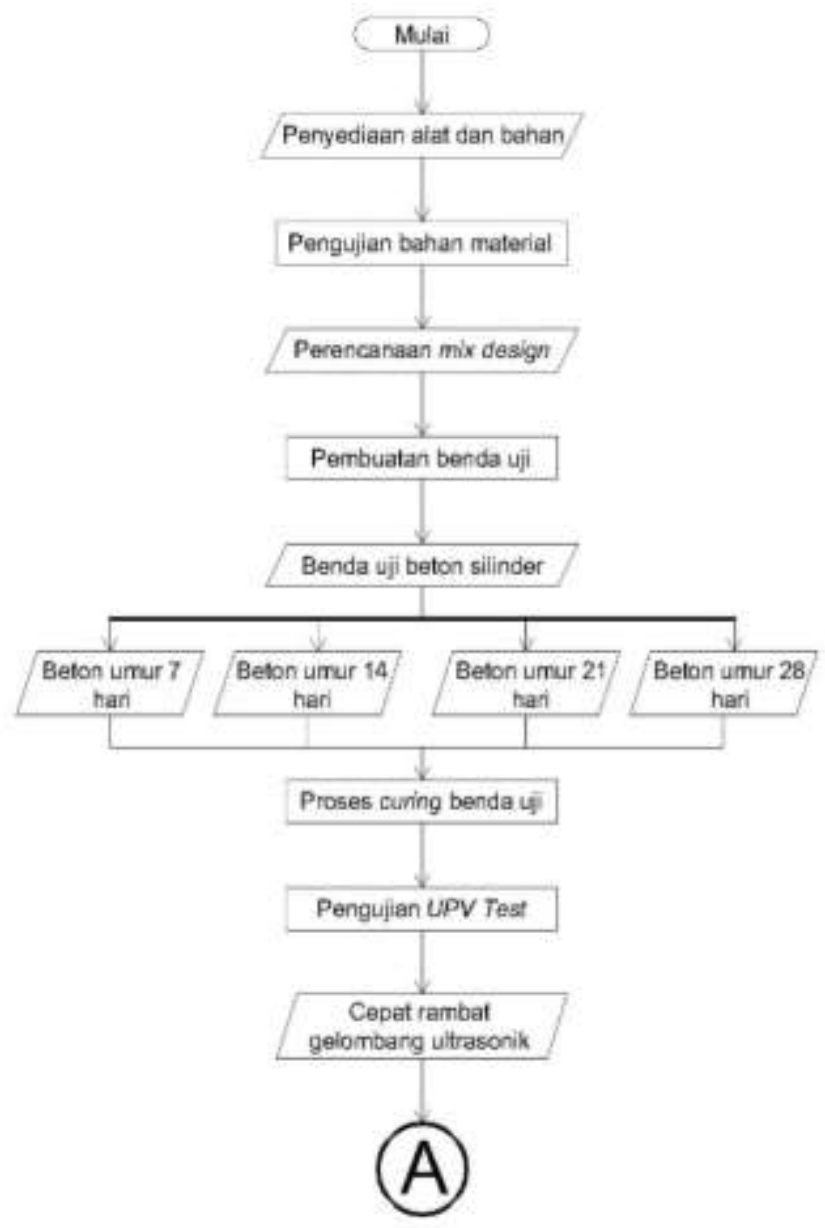

Gambar 2. Flowchart Penelitian 


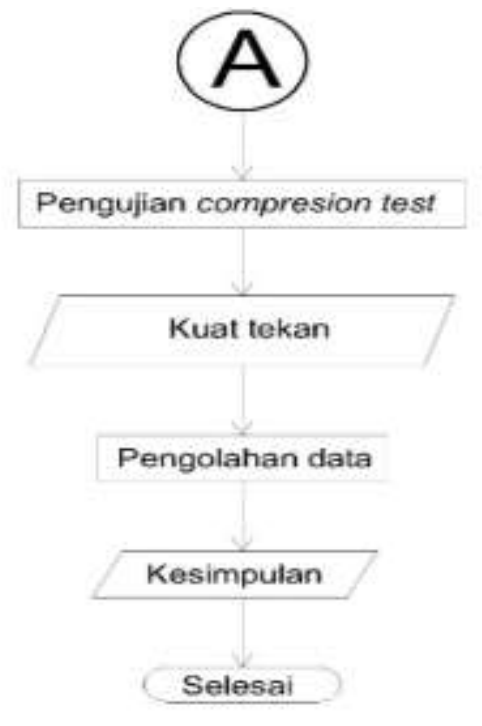

Gambar 2. Flowchart penelitian (lanjutan)

\subsection{Rancangan Penelitian}

Penelitian ini menggunakan benda uji beton normal silinder dengan ukuran diameter $15 \mathrm{~cm}$ dan tinggi $30 \mathrm{~cm}$. Digunakan 36 benda uji yang dibagi menjadi 4 umur beton yang berbeda, dan mutu yang digunakan 12,5 Mpa, 18,75 Mpa, dan $25 \mathrm{Mpa}$. Rincian komposisi benda uji bersasarkan dapat dilihat pada Tabel 2.

Tabel 2. Komposisi Rasio Mix Design Beton

\begin{tabular}{|c|c|c|c|c|c|}
\hline $\begin{array}{l}\text { Mena } \\
\text { Betes }\end{array}$ & Semin & Air & $\begin{array}{l}\text { Agrrat } \\
\text { Hales }\end{array}$ & $\begin{array}{l}\text { Aereat } \\
\text { Kisar }\end{array}$ & Jualah \\
\hline $\begin{array}{c}\text { Besce } \\
\text { fr 125sea }\end{array}$ & 1 & 0,432 & 252 & A.II & 12 \\
\hline $\begin{array}{c}\text { Betm } \\
\text { fc. 15,75 M?: }\end{array}$ & 1 & 0,466 & 2.24 & 3,90 & 12 \\
\hline $\begin{array}{c}\text { Betw } \\
\text { fasmas }\end{array}$ & 1 & IH34 & 1,83 & 338 & 12 \\
\hline
\end{tabular}

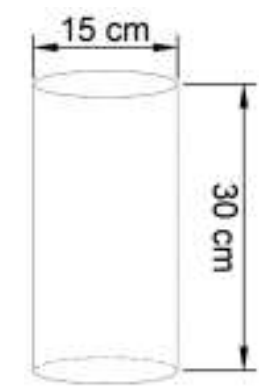

Gambar 3. Dimensi Benda Uji Beton Silinder

\subsection{Pembuatan Benda Uji}

Langkah - langkah pembuatan benda uji silinder antara lain:

1. Langkah pertama adalah mengolesi cetakan silinder dengan oli agar mempermudah untuk dilepaskan ketika beton telah mengeras.

2. Beton segar yang telah selesai diuji slump dan memenuhi persyaratan dimasukkan kedalam cetakan silinder.

3. Pengisiannya hampir sama dengan cara pengujian slump, dengan dimasukkan $1 / 3$ bagian lalu dipadatkan dengan cara ditusuk menggunakan besi sebanyak 25 kali. begitu pula pada lapisan $2 / 3$ dan penuh.

4. Ketika diisi cetakan harus dipukul - pukul menggunakan palu karet agar agregat dapat mengisi rongga udara yang ada.

5. Setelah penuh lalu diratakan dan diamkan hingga mengeras.

\subsection{Pengujian $U P V$}

Beberapa hal yang dilakukan dalam prosedur pengujian UPV antara lain:

1. Meratakan dan membersihkan permukaan beton.

2. Pada penelitian ini digunakan transduser standar dengan frekuensi $54 \mathrm{kHz}$.

3. Mengkalibrasi alat uji UPV dengan tujuan agar pembacaan waktu tempuh pada transmitter dan receiver sama. Kedua transduser ditempatkan pada kedua sisi calibration rod yang telah disediakan.

4. Menentukan jarak transmitter dan receiver pada layar Pundit PL-200.

5. Memberikan gel (couplant) pada permukaan kontak transmitter dan receiver setiap sebelum pengujian dimulai.

6. Pengujian dilakukan pada titik yang telah ditentukan sebelumnya

7. Pengujian UPV telah selesai dan didapatkan hasil berupa bentuk gelombang ultrasonik beserta waktu transmisi dan cepat rambatnya.

\subsection{Pengujian Compression}

Langkah - langkah pengujian kuat tekan dan pembacaan regangan beton adalah sebagai berikut:

1. Pengujian ini dilakukan setelah beton berumur 7, 14, 21, 28 hari.

2. Siapkan benda uji yang telah melewati masa curing dan memenuhi umur. 
3. Meratakan permukaan silinder dengan menggunakan capping.

4. Membuat form pengisian data kuat tekan

5. Mengeset alat compressometer pada posisi angka bacaan nol terlebih dahulu, dan kemudian meletakkan benda uji ke bawah load cell atau tempat uji tekan.

6. Melakukan pengujian, dengan memberikan beban yang menaik dengan kecepatan konstan.

7. Mencatat nilai besarnya nilai kuat tekan yang

dapat ditahan oleh benda uji.

\subsection{Metode Pengolahan Data}

Pengumpulan data pada penelitian ini diambil dari beberapa pengujian yang dilakukan ketika beton berumur 7, 14, 21, 28 hari. Dengan mutu beton yang berbeda. Lalu dilakukan pengujian $U P V$ untuk mendapatkan data berupa waveform dan juga kecepatan gelombang ultarasonik yang diterima oleh receiver. Hasil dari percobaan tersebut lalu diolah menggunakan aplikasi PL-Link agar mendapat parameter cepat rambat gelombang. Lalu dilakukan juga pengujian Compresion test. Pengujian ini dilakukan untuk mendapatkan korelasi antara cepat rambat gelombang ultrasonik dan juga kuat tekan beton .

\section{HASIL DAN PEMBAHASAN \\ 4.1. Pengujian Ultrasonic Pulse Velocity (UPV)}

Pengujian $U P V$ dilakukan pada semua benda uji silinder dengan umur yang berbeda beda yaitu 7, 14, 21, 28 hari. Untuk pengujian $U P V$, alat yang digunakan adalah PUNDIT PL200 milik PROCEQ dan mode pengukuran yang digunakan pada penelitian ini yaitu pulse velocity $(P V)$ untuk mengetahui berapa kecepatan yang dibutuhkan gelombang ultrasonik untuk melewati material beton yang menghasilkan output cepat rambat gelombang dengan satuan $(\mathrm{m} / \mathrm{s})$.

Didapatkan hasil UPV mengalami peningkatan pada setiap tinjauan umur. Namun hasil $U P V$ pada umur 7 hari Menurut tabel 2.3 termasuk dalam kategori jelek yaitu rata rata $2831 \mathrm{~m} / \mathrm{s}$. Hal ini dapat disebabkan oleh beberapa sebab antara lain : 1) Terdapat rongga pada benda uji beton. 2) Belum optimalnya proses pengikatan antar material pada umur 7 hari. Karena pada prinsipnya jika gelombang
$U P V$ mengenai rongga maka hasil kecepatan gelombang merambat akan semakin buruk.

Tabel 3. Hasil Pengujian UPV Pada Benda Uji Mutu 12,5 Mpa

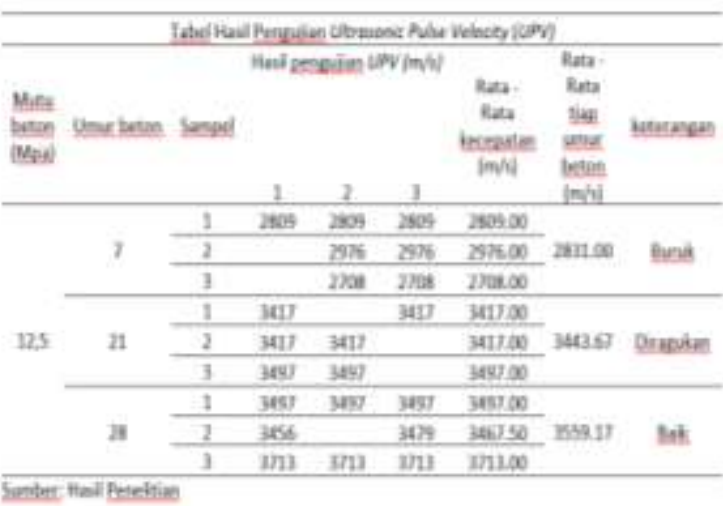

Grafik Hasil Pengujian Uitrasonic Pulse Velocity (UPV) 12,5 Mpa

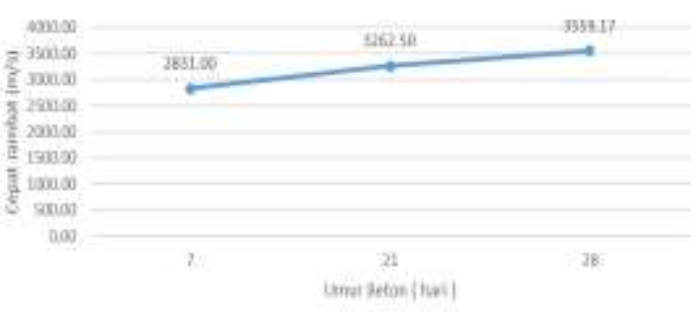

Gambar 4. Grafik Pengujian UPV Pada Benda Uji Mutu 12,5 Mpa.

Pada pengujian benda uji beton $18,75 \mathrm{Mpa}$ didapatkan hasil yang terus meningkat seiring dengan umur beton. Hasil yang didapat berkisar antara $3300-3600 \mathrm{~m} / \mathrm{s}$ yang dapat dikategorikan diragukan - baik. Hasil baik diperoleh pada umur 28 hari dimana beton telah mengeras dengan sempurna.

Tabel 4. Hasil Pengujian UPV Pada Benda Uji Mutu 18,75 Mpa.

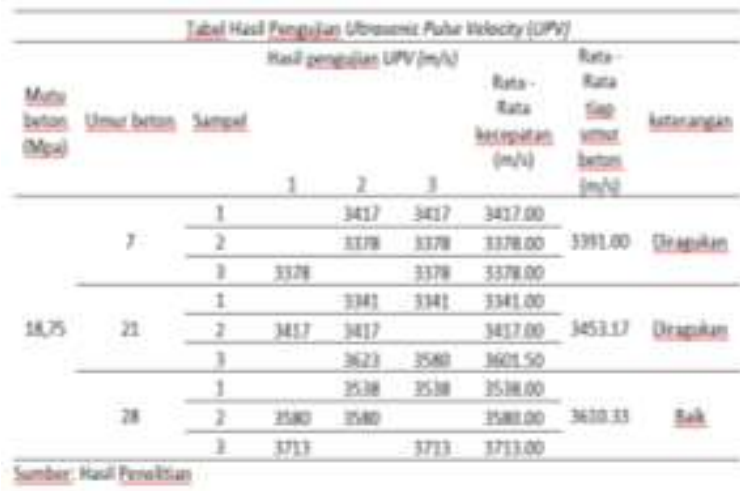




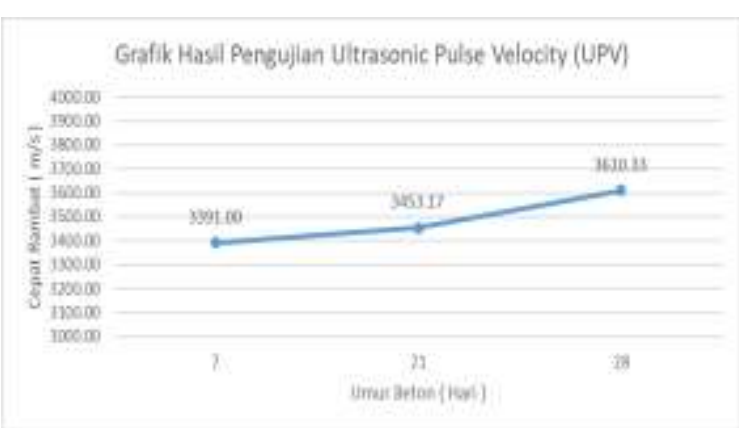

Gambar 5. Grafik Pengujian $U P V$ Pada Benda Uji Mutu 18,75 Mpa

Pengujian $U P V$ juga dilakukan pada benda uji beton mutu $25 \mathrm{Mpa}$ dan mendapatkan hasil $3400-3700 \mathrm{~m} / \mathrm{s}$. Dalam tabel klasifikasi pengujian $U P V$ tabel 2.3 hasil ini dapat dikategorikan baik. Hal ini dipengaruhi oleh mutu beton yang relatif tinggi sehingga kerapatan material pengisinya semakin padat. dapat dilihat bahwa hasil pengujian $U P V$ terus meningkat sampai umur beton 28 hari.

Tabel 5. Hasil Pengujian UPV Pada Benda Uji Mutu $25 \mathrm{Mpa}$
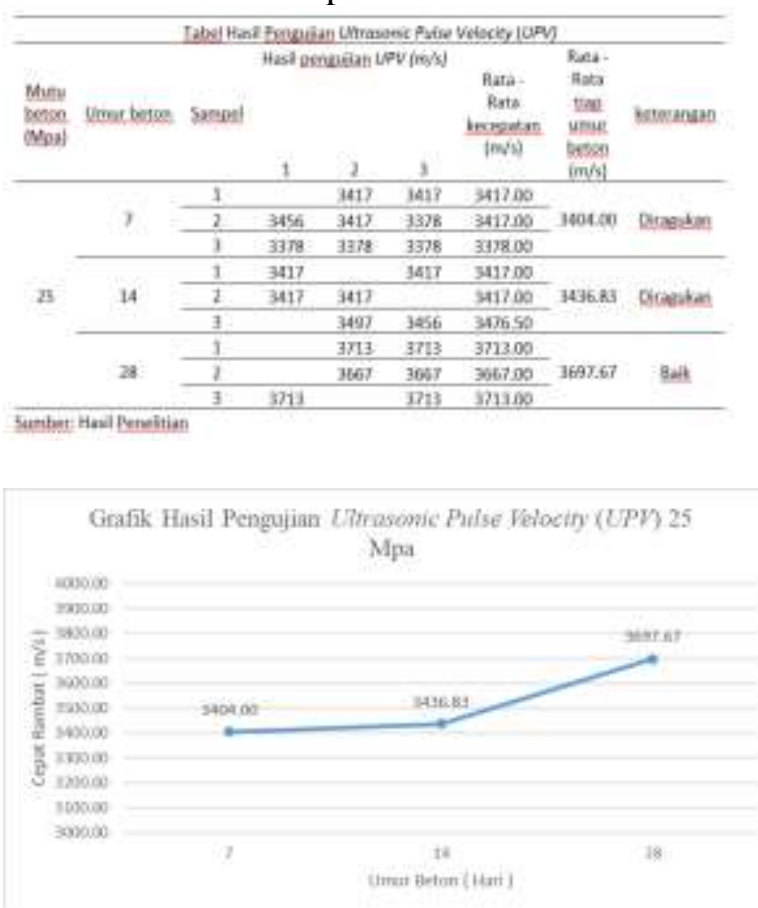

Gambar 6. Grafik Pengujian $U P V$ Pada Benda Uji Mutu $25 \mathrm{Mpa}$

\subsection{Pengujian Compression}

Pengujian kuat tekan dilakukan sebagai controlling mutu beton yang direncanakan pada mix design dan mengetahui kekuatan beton untuk menahan beban yang diberikan oleh alat Compression Test Machine, sehingga dapat diketahui nilai kuat tekan aktual dari beton yang diuji. Benda uji yang digunakan pada pengujian ini berjumlah 9 buah benda uji silinder dengan 3 mutu yang berbeda, masing masing mutu berjumlah 3 benda uji.

Tabel 6. Hasil Pengujian Kuat Tekan Pada Benda Uji Mutu 12,5 Mpa.

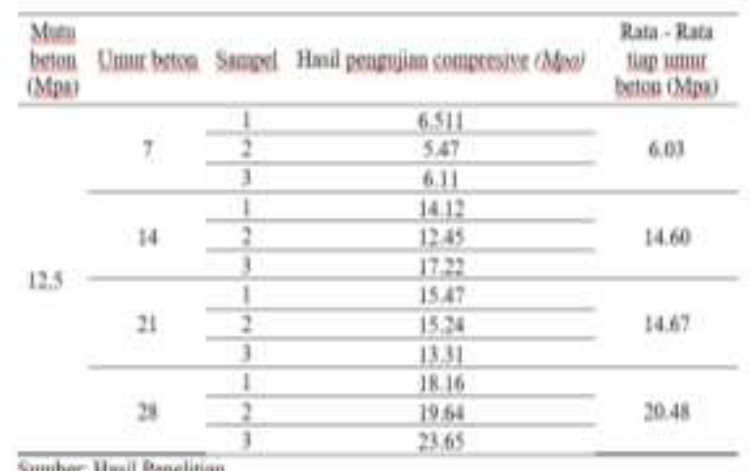

Sumber Hasil Peacitian

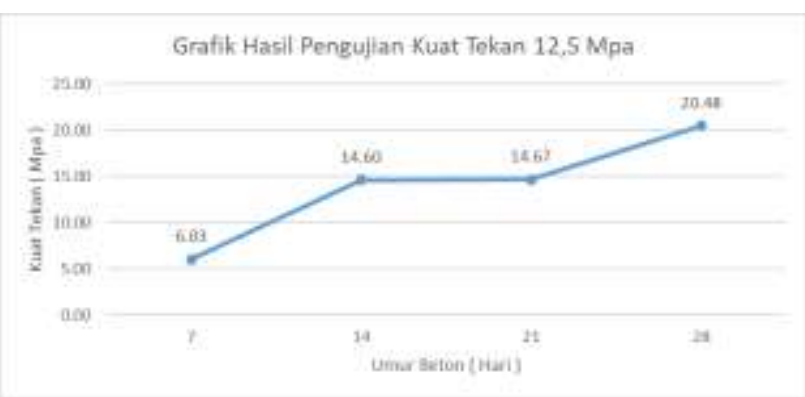

Gambar 7. Grafik Pengujian Compression Pada Benda Uji Mutu 12,5 Mpa.

Nilai kuat tekan terus mengalami kenaikkan hingga umur 28 hari. Pada umur 7 hari kuat tekan aktual yang didapat hanya 6,03 Mpa. Namun, pada umur 28 hari kuat tekan aktual telah mencapai 20,48 Mpa. Nilai kuat tekan tersebut lebih kuat 7,98 Mpa dari mutu rencana. Namun pada umur 14 dan 21 hari kenaikannya hanya $0,7 \mathrm{Mpa}$ hal ini dapat disebabkan karena terbatasnya volume Concreate mixer Sehingga pada saat pengecoran tidak dilakukan pada 1 adukan sehingga homogenitasnya rendah. 
Tabel 7. Hasil Pengujian Kuat Tekan Pada Benda Uji Mutu 18,75 Mpa
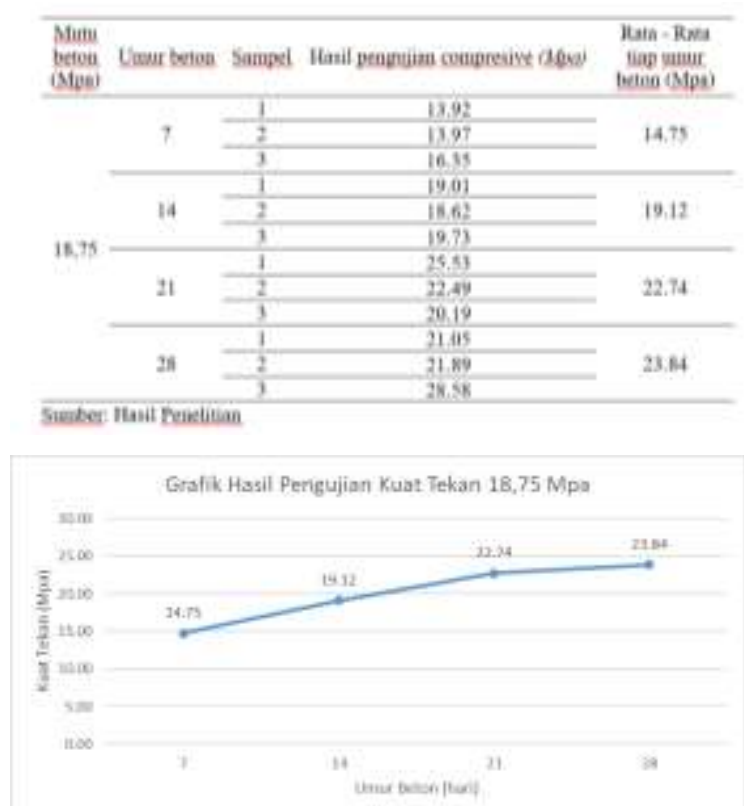

Gambar 8. Grafik Pengujian Compression Pada Benda Uji Mutu 18,75 Mpa

Hampir sama dengan pengujian yang dilakukan pada mutu 12,5 Mpa pada pengujian mutu beton 18,75 Mpa didapatkan nilai kuat tekan yang terus meningkat sampai berumur 28 hari dengan hasil 23,84 lebih kuat 5,09 Mpa dari kuat tekan rencana. Kenaikan kuat tekan beton dari umur yang ditinjau relatif hampir sama berkisar antara 1,1-5 Mpa.

Tabel 8. Hasil Pengujian Kuat Tekan Pada Benda Uji Mutu $25 \mathrm{Mpa}$

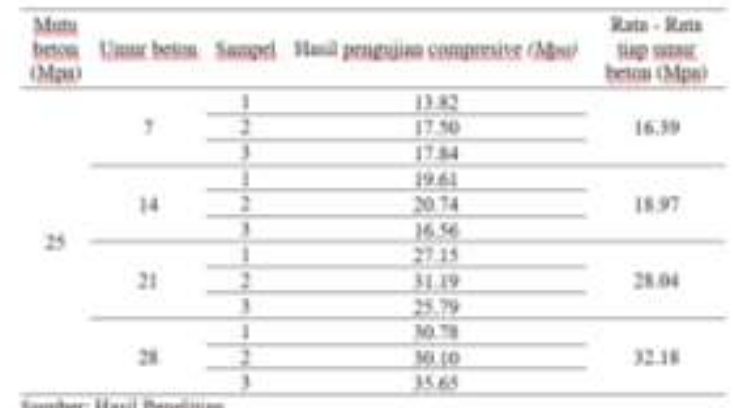

Pada beton mutu 25 Mpa hasil kuat tekan beton juga terus meningkat seiring dengan umur beton. Dan juga hasil dari kuat tekan aktual lebih kuat 7,18 Mpa dari kuat tekan rencana.
Kenaikan pada mutu beton ini dapat diakibatkan oleh beberapa faktor. Antara lain karena pemadatan pada lapisan permukaan terlalu baik, sehingga beban yang dapat ditahan oleh beton melebihi kuat tekan rencana. Faktor lain dapat berupa campuran mix design karena campuran yang digunakan telah dikalikan faktor keamanan $5 \%$

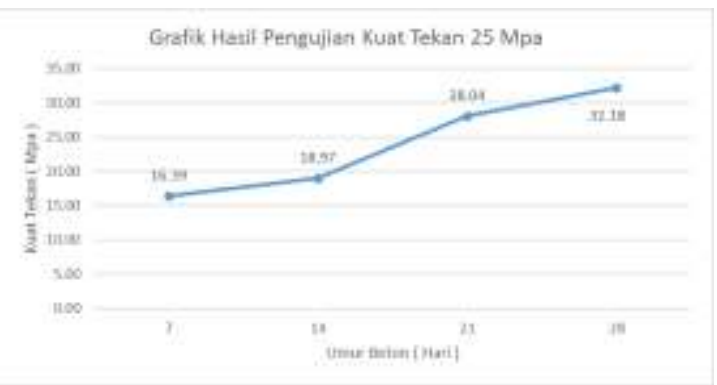

Gambar 9. Grafik Pengujian Compression Pada Benda Uji Mutu 25 Mpa

\subsection{Hubungan Antara Compression Test dan UPV Test}

Setelah dilakukan pengujian $U P V$ dan kuat tekan maka didapat data - data berupa cepat rambat gelombang dan nilai kuat tekan aktual. Untuk mendapatkan hubungan antara cepat rambat gelombang dan nilai kuat tekan beton aktual dilakukan regresi eksponensial sehingga mendapatkan grafik hubungan. Grafik ini pula juga akan menampilkan nila $\mathrm{R}^{2}$ yaitu koefisien determinasi. Data akan semakin baik jika nilai $\mathrm{R}^{2}$ makin mendekati 1 .

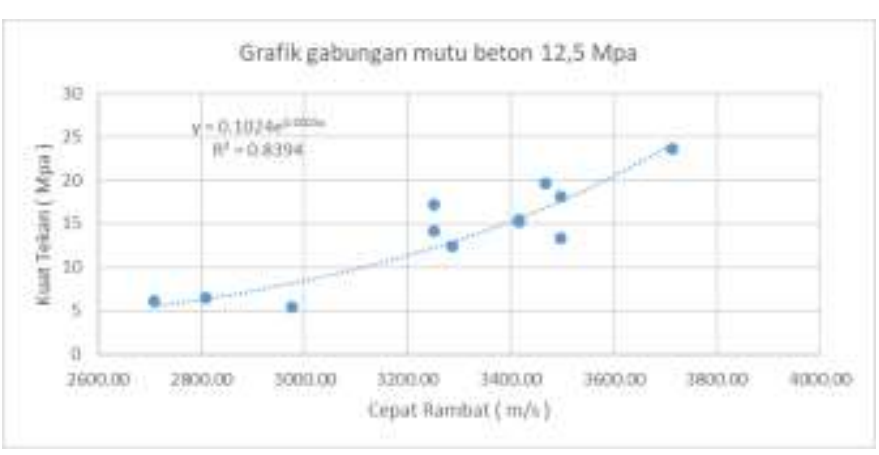

Gambar 10. Grafik Hubungan Antara Cepat Rambat Gelombang dan Kuat Tekan Pada Benda Uji 12,5 Mpa 


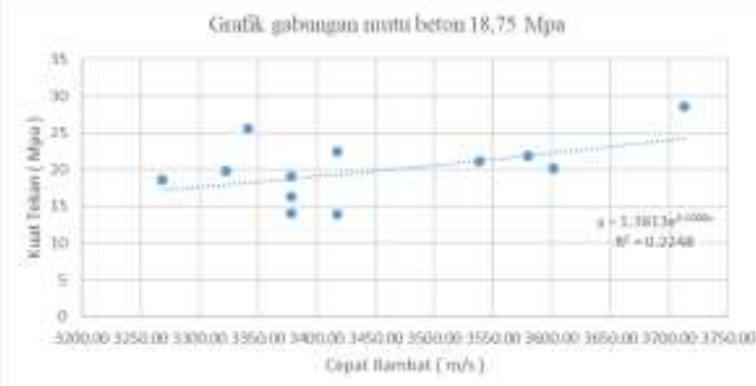

Gambar 11. Grafik Hubungan Antara Cepat Rambat Gelombang dan Kuat Tekan Pada Benda Uji 18,75 Mpa

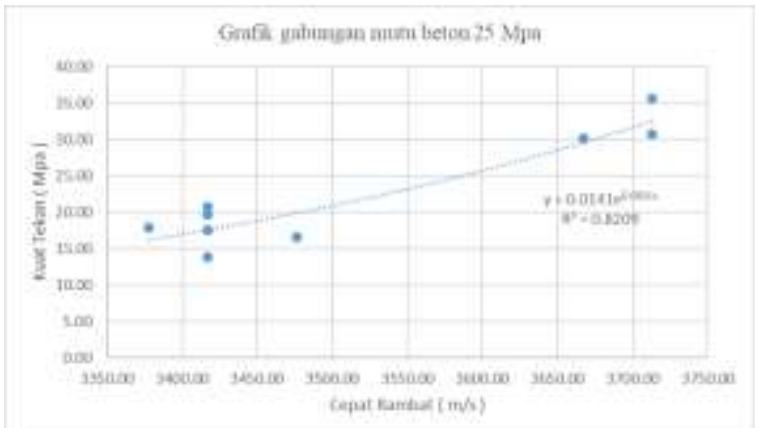

Gambar 12. Grafik Hubungan Antara Cepat Rambat Gelombang dan Kuat Tekan Pada Benda Uji $25 \mathrm{Mpa}$

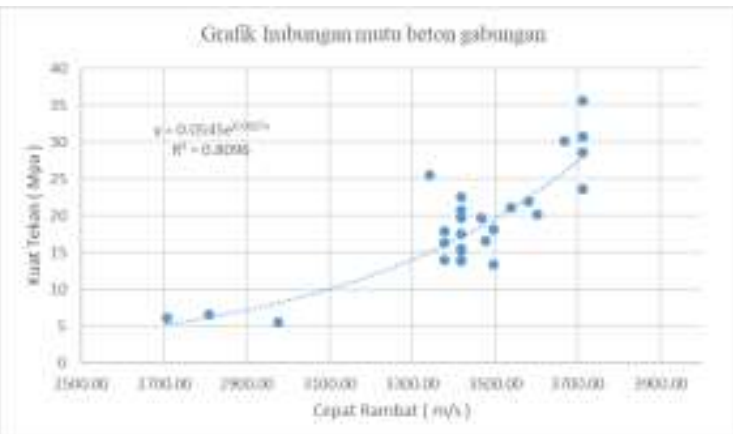

Gambar 13. Grafik Hubungan Antara Cepat Rambat Gelombang dan Kuat Tekan Pada Semua Benda Uji

Pada grafik pengolahan data pada beton mutu rencana $12,5 \mathrm{Mpa}$ didapat hasil trendline yang meningkat dengan nilai $\mathrm{R}^{2}$ yaitu 0,8394 . Hal ini membuktikan bahwa pada beton mutu rencana 12,5 Mpa dengan data umur yang ditinjau terdapat hubungan yang valid antara $U P V$ dan kuat tekan. Namun pada benda uji beton dengan mutu rencana $18,75 \mathrm{Mpa}$ nilai $\mathrm{R}^{2}$ hanya 0,2248 . Hal itu dapat disebabkan oleh beberapa faktor yaitu, perbedaan proses pencampuran yang tidak satu adukan sehingga memiliki nilai homogenitas yang rendah, tidak stabilnya alat transducer dan receiver sehingga energi gelombang menyebar dari lintasan awalnya. Selain itu proses pemadatan yang masih menggunakan cara konvensional yaitu dengan cara dirojok dan dipukul - pukul menggunakan palu karet. Dengan cara seperti itu kemungkinan terdapat rongga udara di dalam beton sangat besar. Faktor lain yaitu dengan ukuran agregat yang tidak well graded atau bergradasi buruk. Jadi ketika proses pemadatan agregat tidak mengisi semua rongga yang ada. Oleh karena itu hubungan antara pengujian $U P V$ dan pengujian kuat tekan pada beton mutu rencana 18,75 Mpa dikatakan buruk. Dan pada benda uji beton dengan mutu rencana $25 \mathrm{Mpa}$ didapat nilai $\mathrm{R}^{2}$ yang cukup tinggi yaitu 0,8209 dengan nilai itu maka hubungan yang didapat cukup baik. Setelah data dikelompokkan berdasarkan mutu maka data diinput semua kedalam suatu grafik untuk mendapatkan hubungan pengujian pada ketiga mutu yang ditinjau. Pada grafik gabungan didapatkan nilai $\mathrm{R}^{2}$ sebesar 0,8096 .

\section{PENUTUP}

\subsection{Kesimpulan}

Dari hasil penelitian ini dapat diambil kesimpulan sebagai berikut:

1. Hasil pengujian $U P V$ mengalami kenaikan seiring dengan umur beton tersebut. Hasil Pengujian UPV Merupakan gambaran dari kerapatan partikel penyusun beton pada bagian inti atau bagian dalam beton. Hasil yang kurang optimal ini dapat disebabkan oleh proses pemadatan yang tidak merata pada setiap lapisan beton. Sehingga pada bagian inti beton masih terdapat rongga udara yang membuat energi gelombang terdistraksi dari lintasan awal. Faktor lain adalah karena pada pengujian benda uji yang digunakan pada setiap umur berbedabeda sehingga nilai homogenitasnya rendah.

2. Pada pengujian kuat tekan juga didapatkan hasil yang terus meningkat dari umur 7 hingga 28 hari. Pada semua mutu tinjauan didapat hasil kuat tekan aktual yang lebih kuat dibandingkan dengan kuat tekan rencana. Hal ini dapat disebabkan oleh proses pemdatan pada bagian permukaan beton terlalu baik dan juga pada form mix design berat campuran yang digunakan 
telah dikalikan faktor keamanan 5\% sehingga hasil kuat tekan aktual dapat lebih kuat,

3. Dari data yang telah diperoleh semua data diinputkan ke dalam grafik untuk menunjukkan hubungan antara pengujian $U P V$ dan pengujian kuat tekan. Grafik yang ditampilkan dikelompokkan berdasarkan mutu beton dengan umur tinjauan 7, 14, 21, 28 hari. Dapat disimpulkan bahwa terdapat hubungan antara pengujian $U P V$ dan pengujian kuat tekan beton pada umur 7, 14, 21, 28 hari dengan mutu 12,5 Mpa, 18,75 Mpa, dan 25 Mpa.

\subsection{Saran}

Menurut penelitian terhadap benda uji silinder dengan berbagai macam variasi umur beton dengan menggunakan alat UPV maka terdapat beberapa saran yang dapat digunakan untuk penelitian selanjutanya, yaitu:

1. Perlu adanya penambahan jumlah sampel pada masing-masing umur beton agar regresi dan korelasi yang telah didapat dapat digunakan secara umum.

2. Pada mutu beton yang sama lebih baik proses pembuatan benda uji berada pada satu adukan agar homogenitas menjadi lebih tinggi.

3. Perlu adanya kontrol yang lebih baik terhadap proses pencampuran serta pemadatan pada setiap lapisan beton.
4. Diperlukan kestabilan transduser dan cairan couplant yang cukup saat pengujian $U P V$ berlangsung.

5. Benda uji yang digunakan sama pada setiap umur yang ditinjau agar mengerti perubahan kerapatan pada setiap umurnya.

\section{DAFTAR PUSTAKA}

[1] Hamidian. 2012. Full Length Research Pa-per, Application of Schmid Rebound Hammer and Ultrasonic Pulse Velocity Tehniques for Structural Health Moni-toring. Journal of Scientific Research and Essays, (Online), Vol 7 (21) pp 1997-2001, 7 June 2012.

[2] Indriani, F. D; Christin R.N.; Ming N.W. Pengaruh Variasi Agregat Kasar Penyusun Beton Terhadap Kerapatan Beton Dengan Menggunakan Transmission Time Pada Alat UPV (Ultrasonic Pulse Velocity). Rekayasa Sipil, Vol.13, No.1, 2019 : 32-39

[3] Herma, E. A; Indradi W; Sugeng P.B. Pengaruh Variasi Agregat Kasar Penyusun Beton Terhadap Kerapatan Beton Dengan Menggunakan Pulse Velocity Pada Alat UPV (Ultrasonic Pulse Velocity). Rekayasa Sipil, Vol.13, No.1, 2019 : 54-63

[4] PROCEQ.(2008). Operating Instructions Ultrasonic Testing Instrument. Switzerland : Proceq.

[5] PROCEQ. (2014). Pundit PL-200 and PE Ultrasonic Training. Switzerland : Proceq.

[6] Sundari, Y. S. Pengaruh Umur Beton Terhadap Nilai Kuat Tekan Pada Mutu Beton. Media SainS, Vol.4, No.1, $2012: 55$ - 61

[7] J.J. Beaudoin, V.S. Ramachandran, A new perspective on the hydration characteristics of cement phases, Cement and Concrete Research 22 (4) (1992) 689-694. 